\title{
Bacteria associated with lionfish (Pterois volitans/miles complex) exhibit antibacterial activity against known fish pathogens
}

\author{
Julia L. Stevens ${ }^{1,2}$, Ronneshia L. Jackson ${ }^{1}$, Julie B. Olson ${ }^{1, *}$ \\ ${ }^{1}$ The University of Alabama, Department of Biological Sciences, Tuscaloosa, Alabama 35487, USA \\ ${ }^{2}$ Present addresses: North Carolina Museum of Natural Sciences, Genomics and Microbiology Lab, Raleigh, 27601 North Carolina, \\ USA, and North Carolina State University, Department of Applied Ecology, Raleigh, 27695 North Carolina, USA
}

\begin{abstract}
Fish support microbial communities that serve a variety of functions, including disease resistance. In addition to fish microbiota acting as a defense against disease, fish mucus often contains antimicrobial compounds. This study investigated the antibacterial activity of bacteria isolated from external surfaces of native (e.g. Indo-Pacific) and invasive (e.g. Western Atlantic, Caribbean) lionfish (Pterois volitans/miles complex) and native Caribbean squirrelfish Holocentrus adscensionis against 6 known fish pathogens (Vibrio spp., Photobacterium damselae), and evaluated the antibacterial activity of lionfish mucus against these pathogens and lionfishand squirrelfish-associated bacteria. The 16S rRNA gene was sequenced for bacteria exhibiting pathogen inhibition, providing information on their taxonomic affiliations. Antibacterial metabolites were produced by $36.2 \%$ (54 of 149) of lionfish-derived bacterial cultures, with similar percentages of producing organisms recovered from the native and invaded ranges. Only 1 of 13 squirrelfish isolates inhibited pathogens. Interestingly, similar genera exhibiting antibacterial activity were detected in both ranges (e.g. Alteromonas, Pseudoalteromonas, Photobacterium), even though previous work suggested that external bacterial communities were not vertically transmitted. Antibacterial activity was detected after $24 \mathrm{~h}$ of growth, and the amount of inhibition did not increase over a $14 \mathrm{~d}$ incubation period. Conversely, organic and aqueous mucus extracts from lionfish were not active against the 6 pathogens or against bacteria isolated from lionfish and squirrelfish. These findings indicate that the external bacterial communities of lionfish may provide disease resistance to their hosts, a trait that would enhance the ability of lionfish to successfully establish as an invasive species.
\end{abstract}

KEY WORDS: Lionfish $\cdot$ Pterois volitans/miles complex $\cdot$ Invasive $\cdot$ Disease resistance $\cdot$ Fish pathogens $\cdot$ Bacterial isolates

\section{INTRODUCTION}

In the marine environment, the surfaces of eukaryotic organisms serve as substrates for the growth of microorganisms and have been shown to support different bacterial communities than what is found in the surrounding seawater (e.g. Taylor et al. 2005, Penesyan et al. 2010, Burke et al. 2011, Stevens \& Olson 2013), suggesting that the bacteria may be specifically adapted to the microenvironment of their

${ }^{*}$ Corresponding author: jolson@as.ua.edu host (Holmström \& Kjelleberg 1999, Harder et al. 2003). Some fish are known to produce antimicrobial compounds as a protective mechanism against pathogens (Hellio et al. 2002, Bragadeeswaran et al. 2011), but apparently healthy fish support microbial communities, indicating that the presence of these microorganisms is not necessarily detrimental but may instead benefit the host (Cahill 1990, Austin 2002). For example, bacteria associated with fish have been shown to aid in disease resistance (Olsson

(C) The authors 2016. Open Access under Creative Commons by Attribution Licence. Use, distribution and reproduction are unrestricted. Authors and original publication must be credited. 
et al. 1992, Sugita et al. 2002, Chabrillón et al. 2005, O'Brien \& Wright 2011), drag reduction (Bernadsky \& Rosenberg 1992), and food digestion (Ganguly \& Prasad 2012, Ray et al. 2012). In return, fish are thought to provide a nutrient-rich surface for bacterial colonization in an otherwise oligotrophic marine environment (Sar \& Rosenberg 1987, Penesyan et al. 2010).

Disease resistance facilitated by microorganisms occurs through both direct and indirect mechanisms. Fish-associated bacteria can directly inhibit the growth of pathogens on the mucosal lining by competing for space (Chabrillón et al. 2005), while indirect antagonism occurs through the production and release of compounds inhibitory to potential pathogens (Chabrillón et al. 2005, O'Brien \& Wright 2011). The host fish will be protected from disease caused by organisms sensitive to these inhibitory compounds (Penesyan et al. 2010). To optimize both direct and indirect disease resistance mechanisms, the host is thought to support a dense, diverse, and nonpathogenic resident microbiota (Verschuere et al. 2000, Chabrillón et al. 2005).

In addition to the protective metabolites produced by their associated microorganisms, some fish also release antimicrobial compounds in their external mucus (reviewed in Ellis 2001). However, studies of fish mucus have primarily focused on freshwater and temperate marine species (Hellio et al. 2002, Fernandes et al. 2004, Bergsson et al. 2005, Subramanian et al. 2008, Bragadeeswaran et al. 2011), thus little is known about antibacterial metabolites in the mucus of fish species with a broader distribution range. One example in the tropical environment showed that the mucus cocoons of the queen parrotfish inhibited the growth of several bacterial fish pathogens (Videler et al. 1999). However, the ability of parrotfish surfaceassociated bacteria to produce the inhibition detected in the mucus was not assessed.

The present study examined potential antibacterial defenses of lionfish (Pterois volitans/miles complex) from both the native Indo-Pacific and the invaded western Atlantic Ocean, and Caribbean squirrelfish (Holocentrus adscensionis). Previous work demonstrated that the bacterial communities associated with invasive lionfish were more diverse than those associated with native squirrelfish, and included no known fish pathogens (Stevens \& Olson 2013). Additionally, lionfish retained a core surface-associated bacterial community in both the native and invaded ranges, suggesting that these associations are species specific and may play an ecological role (Stevens \& Olson 2015). Therefore, the present study investigated the capacity of lionfish- and squirrelfish-asso- ciated bacteria and lionfish mucus to function in pathogen resistance. Additionally, potential mechanisms for pathogen inhibition were examined by investigating the presence of biosynthetic genes for known bioactive molecules, including polyketide synthases (PKS) and non-ribosomal peptide synthetases (NRPS), and the 16S rRNA gene from bacteria demonstrating pathogen inhibition was sequenced.

\section{MATERIALS AND METHODS}

\section{Field collection}

Lionfish were collected from locations within the invaded (Honduras $[\mathrm{n}=5$ ], Key Largo Florida [ $\mathrm{n}=$ 11], Belize [ $\mathrm{n}=7]$, and Bahamas [n = 8]) and native (Taiwan $[\mathrm{n}=9$ ], Philippines $[\mathrm{n}=4]$, and Indonesia $[\mathrm{n}=3]$ ) ranges. In the invaded range, fish were collected by SCUBA divers with pole spears, pithed, and placed into individual Whirl-pak bags (UA IACUC protocol no. 11-358-2). In the native range, fish were collected by SCUBA divers with nets, placed into individual Whirl-pak bags, and released following sample collection. The surface of the skin of each fish was swabbed with a sterile cotton swab, which was placed into $500 \mu \mathrm{l}$ of filter-sterilized $(0.22 \mu \mathrm{m})$ artificial seawater (ASW: $1.9 \mathrm{l} \mathrm{DI} \mathrm{H}_{2} \mathrm{O}, 40.6 \mathrm{~g} \mathrm{NaCl}, 1.16 \mathrm{~g}$ $\mathrm{KCl}, 18.39 \mathrm{~g} \mathrm{MgCl}_{2} \cdot 6 \mathrm{H}_{2} \mathrm{O}, 2.58 \mathrm{~g} \mathrm{CaCl}_{2} \cdot 2 \mathrm{H}_{2} \mathrm{O}, 6.58 \mathrm{~g}$ $\mathrm{Na}_{2} \mathrm{SO}_{4}, 0.32 \mathrm{~g} \mathrm{NaHCO}_{3}, 0.00027 \mathrm{~g} \mathrm{Na}_{2} \mathrm{H}_{2} \mathrm{PO}_{4}$ ) for $\leq 20 \mathrm{~min}$. After vigorously mixing the swab in the ASW, the swab was removed and $100 \mu l$ of the ASW solution was plated onto a Marine Agar 2216 (MA, Difco) plate. A 1:100 dilution of the inoculated ASW solution was made and $100 \mu \mathrm{l}$ was plated onto another MA plate. The plates were sealed with Parafilm, maintained at room temperature, and transported to the laboratory. To provide a comparison with native Caribbean fish, bacteria from the mucus of squirrelfish were also isolated as described above. Individual colonies were streaked for isolation onto fresh MA plates and grown for 24 to $48 \mathrm{~h}$ at room temperature $\left(\sim 24^{\circ} \mathrm{C}\right)$. Following incubation, isolated strains were transferred to MA slants.

Mucus was collected from lionfish in Belize $(n=12)$ and the Bahamas $(\mathrm{n}=12)$ by adding $10 \mathrm{ml}$ of a $100 \mathrm{mM} \mathrm{NaCl}$ solution to a Whirl-pak containing only the pithed fish. The fish was carefully moved back and forth in the solution for $\sim 1$ min to slough off the mucus (Subramanian et al. 2008). The resulting mucus-salt solution was collected in $15 \mathrm{ml}$ sterile centrifuge tubes and immediately frozen at $-20^{\circ} \mathrm{C}$ until use. 


\section{Culture screening for potential antibacterial activity}

Known fish pathogens Vibrio vulnificus (2 strains: 1-FT-1, 76-FC-1), V. parahaemolyticus (2 strains: DIST-7, LA-4T-1), and $V$. harveyi (strain VH536ED) were generously provided by C. Arias (Auburn University). Photobacterium damselae ssp. piscicida (strain DSMZ 22834) was purchased from the German Collection of Microorganisms and Cell Cultures. All pathogens were grown in marine broth $\left(\mathrm{MB}^{\circ}\right.$ Difco) overnight at $30^{\circ} \mathrm{C}$ with shaking (220 rpm). Using a hemocytometer, cell concentrations were standardized to approximately $1 \times 10^{7} \mathrm{cells} \mathrm{ml}^{-1}$. Seeded plates were made by adding $1 \mathrm{ml}$ of the standardized cell solution to $100 \mathrm{ml}$ of molten MA, mixing thoroughly, and placing $10 \mathrm{ml}$ aliquots of the inoculated medium into square Petri dishes $(100 \times$ $100 \mathrm{~mm}$; Fisher Scientific). All seeded plates had a final concentration of approximately $1 \times 10^{5} \mathrm{cells} \mathrm{ml}^{-1}$ and were stored at $4{ }^{\circ} \mathrm{C}$ and used within $48 \mathrm{~h}$.

All lionfish- and squirrelfish-associated isolates were grown in individual culture tubes containing $10 \mathrm{ml}$ of SYZ-ASW broth (soluble starch $15 \mathrm{~g}$, yeast extract $2 \mathrm{~g}$, NZ-amine $4 \mathrm{~g}$, dextrose $2 \mathrm{~g}$, ASW $750 \mathrm{ml}$, DI $\mathrm{H}_{2} \mathrm{O} 250 \mathrm{ml}$ ) for $14 \mathrm{~d}$ at $30^{\circ} \mathrm{C}$ with shaking (220 rpm) in a New Brunswick Scientific C25 incubator shaker. After growth, $1 \mathrm{ml}$ portions of the bacterial liquid cultures were transferred to $1.5 \mathrm{ml}$ sterile microcentrifuge tubes and centrifuged for $3 \mathrm{~min}$ at $16200 \times g$ in an Eppendorf 5415D tabletop centrifuge to pellet cells. Filter paper disks $(n=6)$ were infused with $20 \mu \mathrm{l}$ of the cell-free supernatant (CFS) from each isolate and placed onto plates seeded with each fish pathogen. For a positive control, a disk infused with $10 \mu \mathrm{g}$ gentamicin (BD BBL Sensi-Disc) was placed onto the agar surface of each plate. Plates were incubated for $24 \mathrm{~h}$ at $37^{\circ} \mathrm{C}(\mathrm{V}$. vulnificus strains, $V$. parahaemolyticus strains, and $V$. harveyi) or $28^{\circ} \mathrm{C}$ (P. damselae ssp. piscicida). Following incubation, plates were examined for the presence of zones of growth inhibition around the disks. When present, zones of inhibition were measured to the nearest $0.5 \mathrm{~mm}$.

\section{Growth inhibition assays}

Cultures that were active against more than one of the pathogens $(n=23)$ were regrown for $14 \mathrm{~d}$ and CFSs prepared as above. Microtitre plates were prepared by making dilutions of the CFS in MB. For each culture, triplicate wells containing CFS concen- trations of $100 \%$ (undiluted), $50 \%$ (1:1 dilution), $25 \%$ (1:3 dilution), and $12.5 \%$ (1:7 dilution) were used in the assay. To the $50 \mu \mathrm{l}$ volumes of CFS (undiluted and diluted), $10 \mu \mathrm{l}$ of an overnight culture of $V$. parahaemolyticus DI-ST-7 standardized to $2 \times 10^{4}$ cells $\mathrm{ml}^{-1}$ in MB was added to each well. Triplicate control wells were inoculated with $60 \mu \mathrm{l} \mathrm{MB}$ (negative control), and $10 \mu \mathrm{l}$ pathogen and $50 \mu \mathrm{l} \mathrm{MB}$ (positive control). The final volume per well was $60 \mu$ l. Plates were incubated overnight at $37^{\circ} \mathrm{C}$ with shaking and the absorbance in each well was measured at $600 \mathrm{~nm}$ on a $\mu$ Quant Universal Microplate Spectrophotometer (Bio-Tek Instruments).

Absorbance measurements were converted to percent pathogen inhibition using the absorbance values from the control wells. Once converted, means and standard deviations for the percent of pathogen inhibition were calculated and linear regression was conducted to test for overall effects of dilution on inhibition. One-way ANOVA was used to test for the effect of dilution on inhibition for each strain individually.

\section{Initiation of secondary metabolite production}

To assess when antibacterial metabolite production began in lionfish-associated bacteria, 6 isolates ( 3 per range, native and invaded) were grown to exponential phase before $500 \mu \mathrm{l}$ volumes were preserved in $15 \%$ glycerol and frozen. Ten ml SYZ-ASW tubes were inoculated daily for $14 \mathrm{~d}$ with the preserved cells at a 1:200 dilution so that each tube received the same inoculum. After the $14 \mathrm{~d}$, CFSs were prepared for the 14 cultures for each isolate. Microtitre plates were prepared and incubated as above with $2 \times 10^{4}$ cells $\mathrm{ml}^{-1}$ liquid culture of $V$. parahaemolyticus DIST-7 to test pathogen growth inhibition. Linear regression was used to test for the effects of dilution and time on pathogen inhibition.

\section{Taxonomic affiliations of bacteria that produced antibacterial metabolites}

DNA was extracted from the isolates that demonstrated antibacterial activity by placing cells into $100 \mu \mathrm{l}$ of a sterile $5 \%$ Chelex 100 resin (Bio-Rad Laboratories) in water solution in a sterile $1.5 \mathrm{ml}$ microcentrifuge tube. Each tube was vortexed for $30 \mathrm{~s}$, incubated at $70^{\circ} \mathrm{C}$ for $15 \mathrm{~min}$, vortexed again for $30 \mathrm{~s}$, and placed on ice for $30 \mathrm{~min}$. This cycle was repeated 3 times before microcentrifuge tubes were centri- 
fuged for $1 \mathrm{~min}$ at $16200 \times g$ to pellet Chelex beads and cellular debris. The supernatants were used for subsequent amplification reactions.

PCR was performed using universal prokaryotic primers 8F (5'-AGAGTTTGATCMTGGCTCAG-3'; Edwards et al. 1989) and 1392R (5'-ACGGGCGGTGTGTACA-3'; Lane 1991) to amplify an approximately 1385 bp region of the 16S rRNA gene. Each reaction consisted of $1.25 \mathrm{U}$ PerfectTaq (5-Prime), $1 \mathrm{X}$ PerfectTaq buffer, $1.25 \mathrm{mM} \mathrm{Mg}(\mathrm{OAc})_{2}, 0.06 \mathrm{mM}$ deoxynucleoside triphosphates, $25 \mathrm{pmol}$ of each primer, $4 \mu \mathrm{l}$ of DNA and sterile DI water to a final volume of $25 \mu \mathrm{l}$. Reaction conditions were $85^{\circ} \mathrm{C}$ for $5 \mathrm{~min}$, followed by 25 cycles of $94^{\circ} \mathrm{C}$ for $45 \mathrm{~s}, 62^{\circ} \mathrm{C}$ for $90 \mathrm{~s}$, and $72^{\circ} \mathrm{C}$ for $90 \mathrm{~s}$, with a final $10 \mathrm{~min}$ extension at $72^{\circ} \mathrm{C}$ with ramp speeds at $1^{\circ} \mathrm{C} \mathrm{s}^{-1}$ (Stevens et al. 2013). Amplification products were visualized by electrophoresis on $1.5 \%$ agarose gels containing GelRed (Biotium) for $70 \mathrm{~min}$ at $70 \mathrm{~V}$, and visualized under UV transillumination with a gel imaging system (Fotodyne). Negative reagent controls without template were run with each reaction.

PCR products $(20 \mu \mathrm{l})$ were digested with HaeIII restriction endonuclease (New England BioLabs) for $8 \mathrm{~h}$ at $37^{\circ} \mathrm{C}$ prior to inactivating the enzyme at $80^{\circ} \mathrm{C}$ for $30 \mathrm{~min}$. Digestion products were visualized on $1.5 \%$ agarose gels as described above and banding patterns were compared using Bionumerics v6.6 software (Applied Maths). A representative PCR product for each banding pattern was randomly selected for sequencing, cleaned using the EZNA Cycle Pure Kit (Omega Bio-Tek), and bi-directionally sequenced by Eurofins MWG Operon. Sequences were compared with the NCBI database using the MEGABLAST algorithm. Closely related sequences were included in an RDP alignment to generate a maximum likelihood tree in Geneious v6.1.7 using the PhyML algorithm with 100 bootstraps and the HKY85 model of nucleotide substitution (Fig. 1).

\section{Screening for secondary metabolite biosynthetic genes}

PCR was used to evaluate the presence of genes found within biosynthetic pathways associated with antimicrobial metabolite production. DNA from each active lionfish-associated isolate was screened with primers specific to non-ribosomal peptide synthetase (NRPS; A3F and A7R; Ayuso-Sacido \& Genilloud 2005) and polyketide synthetase (PKS I; K1F and M6R; Ayuso-Sacido \& Genilloud 2005; and PKS II; $\mathrm{KS} \alpha$ and $\mathrm{ACP}$; Seow et al. 1997) genes. Each reaction consisted of $2.5 \mathrm{U}$ PerfectTaq (5-Prime), $1 \mathrm{X}$ PerfectTaq buffer, $1.25 \mathrm{mM} \mathrm{Mg}(\mathrm{OAc})_{2}, 0.06 \mathrm{mM}$ deoxynucleoside triphosphates, $25 \mathrm{pmol}$ of each primer, $5 \%$ dimethyl sulfoxide, $2 \mu \mathrm{l}$ of DNA and sterile DI water to a final volume of $50 \mu \mathrm{l}$. Reaction conditions were $85^{\circ} \mathrm{C}$ for $5 \mathrm{~min}$, followed by 30 cycles of $94^{\circ} \mathrm{C}$ for $1 \mathrm{~min}, 56^{\circ} \mathrm{C}$ for the PKS primers or $60^{\circ} \mathrm{C}$ for the NRPS primers for $90 \mathrm{~s}$, and $72^{\circ} \mathrm{C}$ for $2 \mathrm{~min}$, with a final 10 min extension at $72^{\circ} \mathrm{C}$. Amplification products were visualized by electrophoresis on $1.0 \%$ agarose gels containing GelRed (Biotium) for $70 \mathrm{~min}$ at $70 \mathrm{~V}$, and visualized under UV transillumination with a gel imaging system (Fotodyne). DNA from Streptomyces scopuliridis, a species with known NRPS and PKS type I and II genes, was used as a positive control. Both positive and reagent negative controls were run with each reaction.

\section{Preparation of mucus extracts}

Mucus samples were lyophilized by freezing at $-80^{\circ} \mathrm{C}$ immediately followed by freeze drying in a FreeZone 2.5 benchtop freeze dry system (Labconco) and stored at $-20^{\circ} \mathrm{C}$. Extracts were prepared following Hellio et al. (2002) and Subramanian et al. (2008) with modifications. To prepare organic extracts (polar and nonpolar phases), lyophilized mucus was suspended in $95 \%$ ethanol at a concentration of $1 \mathrm{mg} \mathrm{ml}^{-1}$ and centrifuged in a Sorvall RC6+ centrifuge (Thermo Scientific) for $30 \mathrm{~min}$ at $4^{\circ} \mathrm{C}$ and $11000 \times g$. The supernatant was transferred to a sterile $50 \mathrm{ml}$ conical tube and the pellet was resuspended 2 additional times in the same volume of $95 \%$ ethanol. The 3 supernatants were combined and evaporated under vacuum at $40^{\circ} \mathrm{C}$ using a Rotavapor Collegiate (Buchi). To separate the nonpolar and polar phases of the organic extract, the dried extract was resuspended in $10 \mathrm{ml}$ distilled water and partitioned 3 times with $5 \mathrm{ml}(3 \times 5 \mathrm{ml})$ dichloromethane (DCM). The DCM nonpolar phases were combined and evaporated under a nitrogen stream and the polar phases were combined and lyophilized.

The aqueous extract of mucus was prepared by resuspending lyophilized mucus in sterile distilled water at a concentration of $1 \mathrm{mg} \mathrm{ml}^{-1}$. After a 2-h incubation at $4^{\circ} \mathrm{C}$, the samples were centrifuged at $9500 \times g$ for $10 \mathrm{~min}$ at $4^{\circ} \mathrm{C}$ in a Sorvall RC6+ centrifuge and the supernatant was decanted and lyophilized. Mucus processing resulted in isolation of aqueous and organic extracts, with the organic extract further separated into nonpolar and polar phases. 


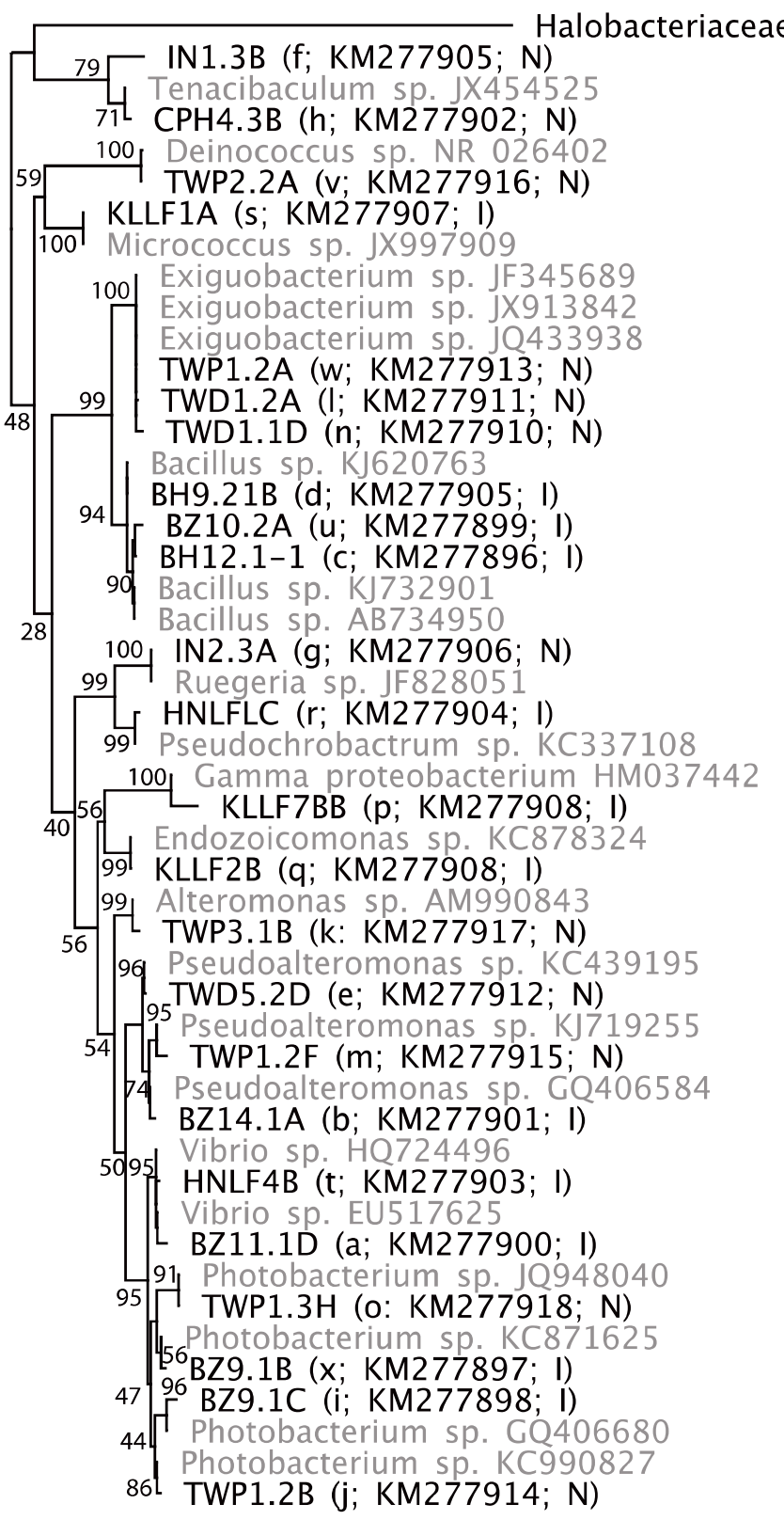

\section{Mucus screening}

The aqueous extract and polar organic phase were resuspended in $1 \mathrm{ml}$ sterile distilled water and the nonpolar organic phase was resuspended in $1 \mathrm{ml}$ of a $5 \%$ DMSO solution (Bergsson et al. 2005). Filter paper disks were infused with $20 \mu \mathrm{l}$ of extract and placed onto seeded plates of the 6 pathogens, 7 lionfish isolates, and 7 squirrelfish isolates. After an overnight incubation at $37^{\circ} \mathrm{C}$ for the Vibrio spp. and $24^{\circ} \mathrm{C}$ for Photobacterium damselae ssp. piscicida and fish-associated isolates, the plates were visually inspected for zones of inhibition. p. GU951430

\begin{tabular}{c||} 
Deinococcus-Thermus \\
Actinobacteria \\
Alpha Proteobacteria
\end{tabular}

\section{RESULTS}

\section{Taxonomic affiliations of bacteria that produced antibacterial metabolites}

A total of 149 bacterial isolates were cultivated from surface swabs of 47 lionfish collected in the native $(\mathrm{n}=16)$ and invaded $(\mathrm{n}=31)$ ranges. After completion of disk diffusion assays on lawns of 6 strains of known fish pathogens, 54 isolates representing 13 bacterial genera showed activity against at least one of the pathogens (Table 1, Fig. 1). Twenty-one of the active isolates were from samples 


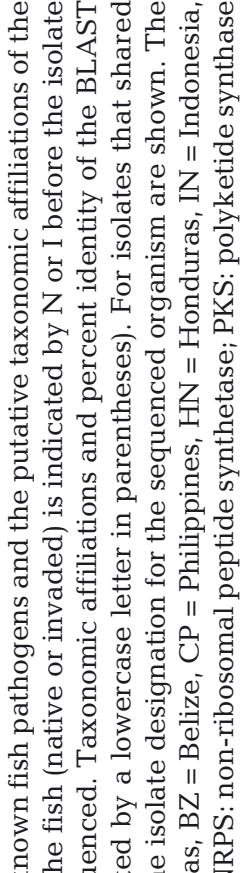

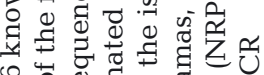

ㄴㅇㅇ क्ष

\& 8 :

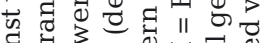

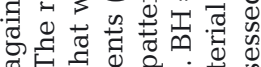

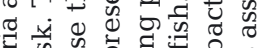

ष्ठ

ชั

ठ

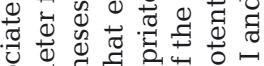

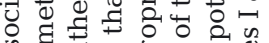

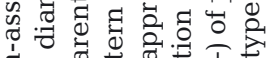

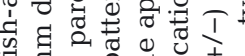

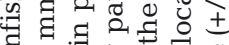

읭

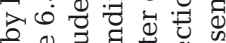

उ

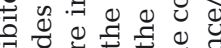

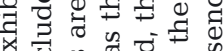

ब.

द ब

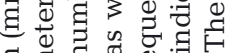

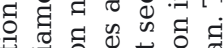

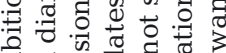

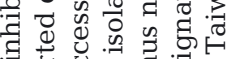

पे

ขै

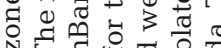

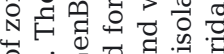

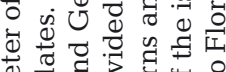

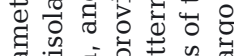

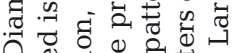

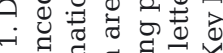

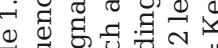

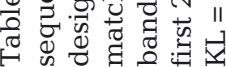

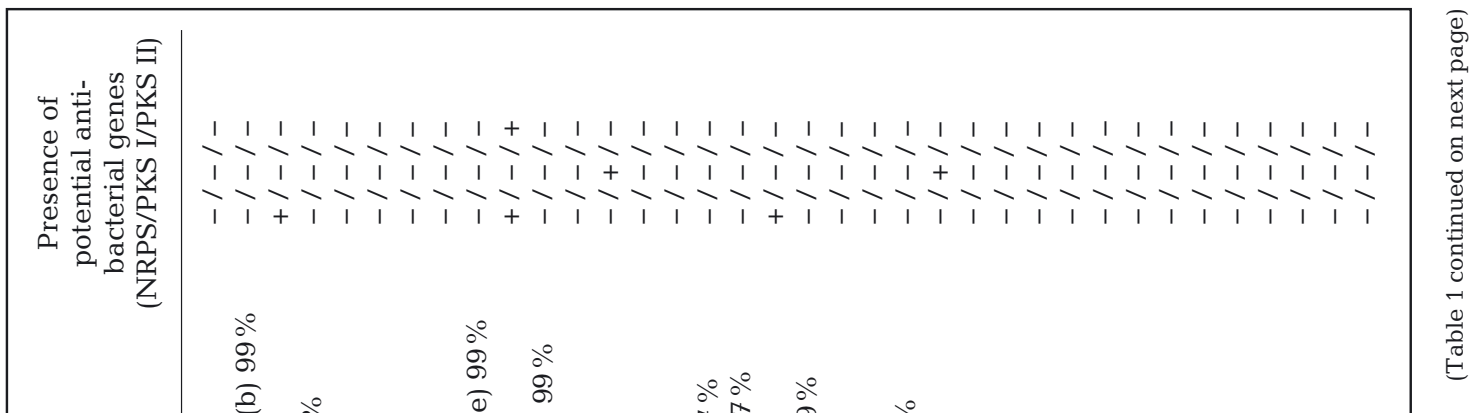

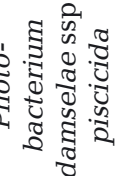

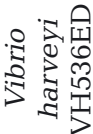

$0000000000000: 0000000000000000000000$

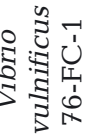

$000000000+\frac{0}{+100} 000000000 \% 0000000: 00000 \%$

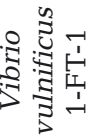

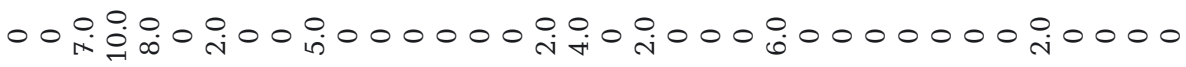

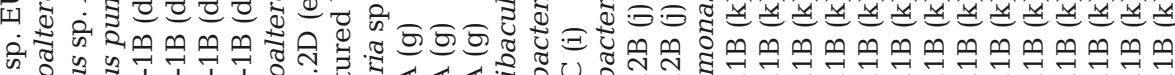

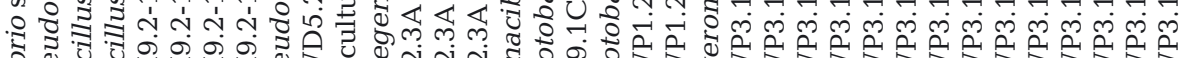

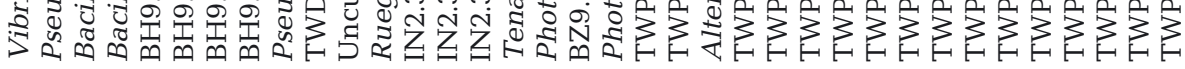

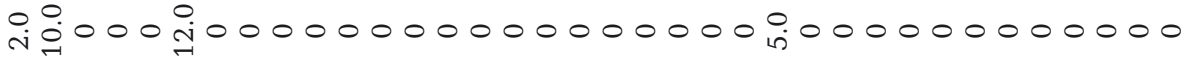

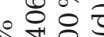

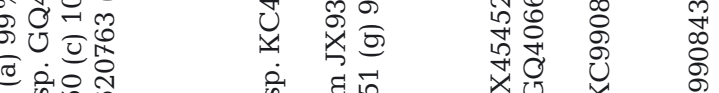

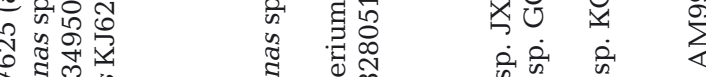

过

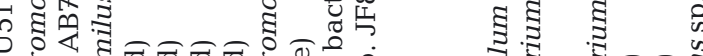

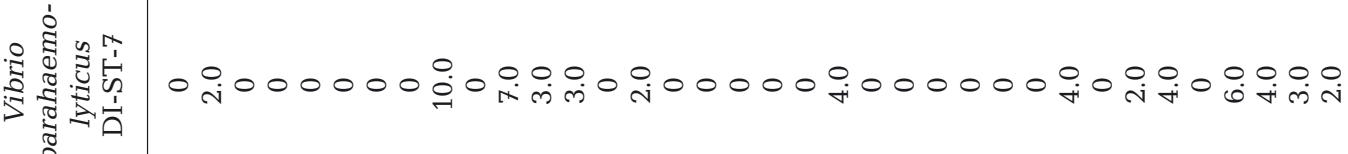

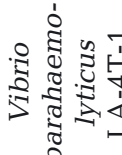

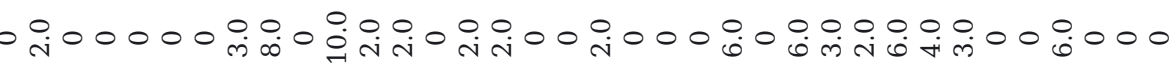

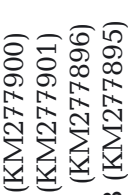

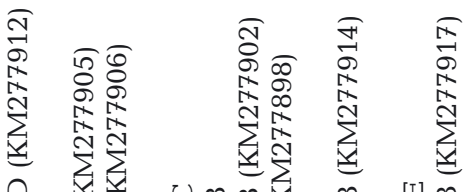

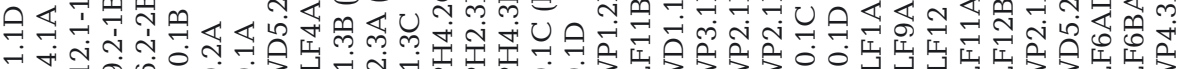

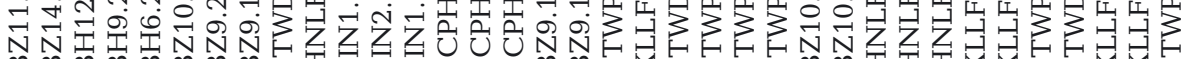

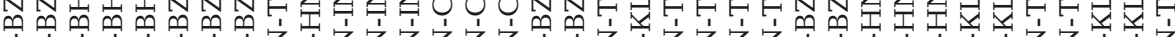




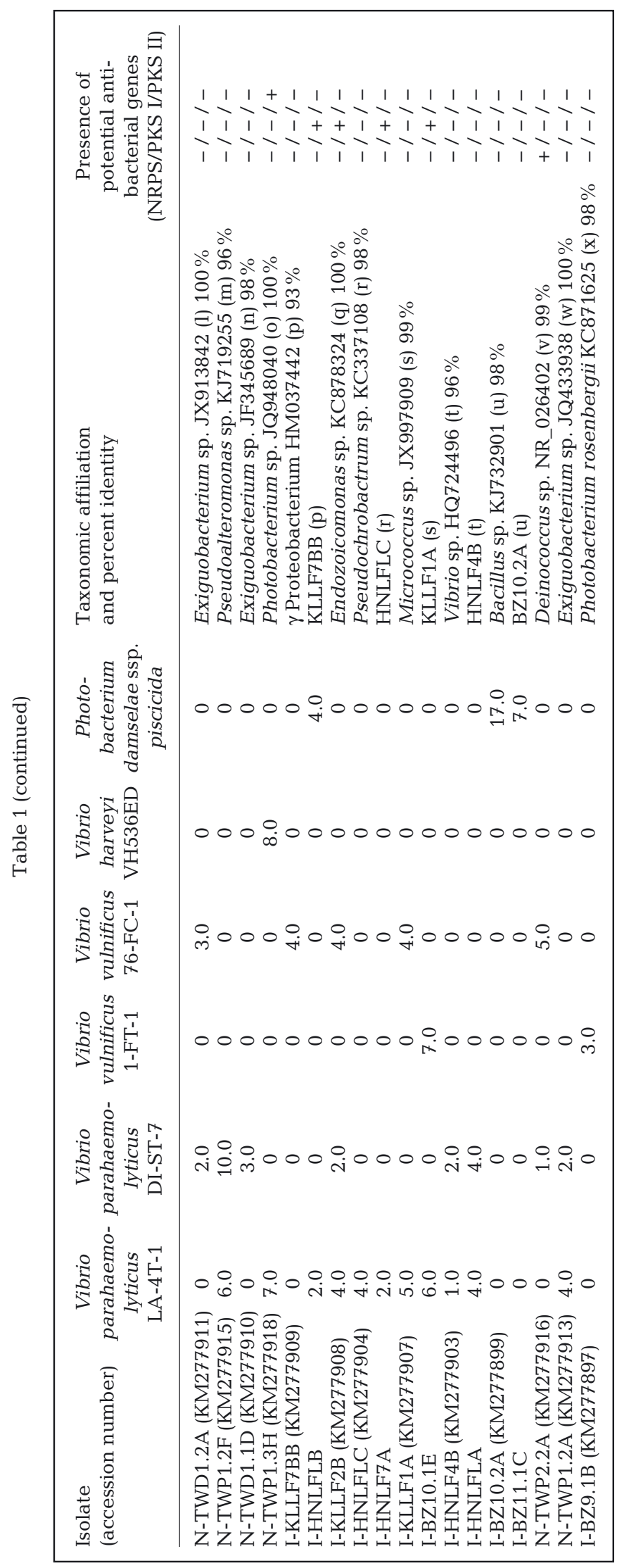

obtained in the native range; the other 33 were obtained from the invaded range. Following gel electrophoresis of HaeIII digested PCR products, the 54 isolates were separated into 24 broad taxonomic groups representing distinct banding patterns; the 16S rRNA gene from a single representative of each group was sequenced and the sequences were submitted to GenBank under accession numbers KM277895-KM277918 (Table 1, Fig. 1). Using similar banding patterns as a proxy for taxonomy, 15 of the 54 isolates were most closely related to Alteromonas spp. (6 from the native range, 9 from the invaded), with another 4 most closely related to Pseudoalteromonas spp. (2 each from the native and invaded ranges). Bacillus spp. and Photobacterium spp. were the closest relatives of 8 (all invaded) and 7 (3 native, 4 invaded) additional isolates, respectively. A single Ruegeria sp. was the closest relative of 4 isolates (all native), while members of the genera Vibrio and Exiguobacterium were each most closely related to 3 isolates (all invaded for Vibrio, all native for Exiguobacterium). Two isolates were each most related to members of the Gammaproteobacteria, Micrococcus, and Pseudochrobactrum (all invaded). Single isolates exhibiting unique banding patterns were most closely related to Bacteroidetes (native), Endozoicomonas (invaded), Deinococcus (native), and Tenacibaculum spp. (native).

\section{Antibacterial activity of lionfish bacterial isolates}

From the native range, $47.7 \%$ (21 of 44 ) isolates showed activity compared with $31.4 \%$ (33 of 105) of isolates from the invaded range. The 2 strains of Vibrio parahaemolyticus were the fish pathogens most commonly inhibited by lionfish-associated bacterial isolates (Table 1); the growth of $V$. parahaemolyticus strain LA-4T-1 was inhibited by 28 isolates whereas strain DI-ST-7 was inhibited by 22 isolates. Twelve and 10 isolates inhibited the growth of $V$. vulnificus strains 1-FT-1 and 76-FC-1, respectively, whereas Photobacterium damselae ssp. piscicida was inhibited by 7 isolates and $V$. harveyi was inhibited by 2 isolates. However, only 10 of the 54 active isolates tested positive for the presence of a gene within characterized NRPS and/or PKS pathways (Table 1).

Within the native Indo-Pacific, lionfish bacterial isolates from 7 genera (Alteromonas, Deinococcus, Exiguobacterium, Photobacterium, Pseudoalteromonas, Ruegeria, and Tenacibaculum) and 1 class (Bacteroidetes) demonstrated activity against the pathogens, while isolates from 8 genera (Alteromonas, Bacillus, 
Endozoicomonas, Micrococcus, Photobacterium, Pseudoalteromonas, Pseudochrobactrum, and Vibrio) cultivated from lionfish in the invaded Western Atlantic were active. Isolates from 3 genera (Alteromonas, Photobacterium, and Pseudoalteromonas) were recovered from lionfish in both ranges, while some of the other genera identified from different ranges belong to the same families (e.g. Bacillus and Exiguobacterium are members of the Bacillales; Vibrio and Photobacterium are members of the Vibrionaceae). The presence of similar genera of skin-associated bacteria that were able to inhibit the growth of known pathogens suggested that the core bacterial community may function in pathogen inhibition.

Interestingly, isolates sharing the same banding pattern from digestion of the amplified 16S rRNA gene did not always exhibit similar antibacterial activity against the 6 tested pathogens. For example, putative species of Alteromonas (banding pattern k; $\mathrm{n}=15$ ) showed considerable variability in antibacterial activity, with at least one isolate active against all of the tested pathogens except $V$. harveyi (Table 1). While differences were noted in the extent of growth inhibition, only isolates within banding patterns $g$ (3 of 4 isolates), i, r, t, and $\mathrm{u}$ displayed activity against the same pathogens.

One of 13 isolates recovered from squirrelfish swabs $(\mathrm{n}=2)$ also showed activity against $V$. parahaemolyticus DI-ST-7, indicating that antibacterial activity of fish-associated bacteria is likely common. This isolate did not inhibit the growth of any of the other fish pathogens. Because of the disparate number of lionfish and squirrelfish isolates tested, direct comparisons cannot be made.

\section{Growth inhibition assays}

Serial dilution of the CFSs significantly impacted the amount of pathogen inhibition for the lionfishassociated bacteria (linear regression, p < 0.0001), with 21 of the 23 isolates showing a significant reduction in antibacterial activity with increasing dilution (Fig. 2). One of the exceptions, an isolate obtained from a lionfish in Belize (BZ14.1A), maintained greater than $67 \%$ growth inhibition of $V$. parahaemolyticus strain DI-ST-7 in all dilutions of CFS tested (12.5 to $100 \%$ ). Only the $100 \%$ and $12.5 \%$ CFS concentrations were significantly different (ANOVA, $\mathrm{p}=0.03$ ) for this isolate. The second exception, an isolate from a fish in the native range (IN1.3C), showed greater than $30 \%$ growth inhibition in all dilutions tested. Overall, the interaction between isolate and CFS dilution had a significant effect on percent pathogen inhibition (ANOVA, p $<0.0001$ ).

When isolates were grouped by the range of their lionfish host (native or invaded), there were no differences in the amount of pathogen inhibition (ANOVA, $\mathrm{p}>0.05)$. The mean $( \pm \mathrm{SD})$ percent pathogen inhibition of isolates was $47.81 \pm 22.57 \%$ and $51.37 \pm$ $26.76 \%$ for lionfish caught in the native and invaded ranges, respectively.

\section{Metabolite production initiation assays}

To evaluate whether antibacterial activity was being appropriately captured in our disk diffusion and growth inhibition assays, which used 2-wk-old cultures, broth cultures were inoculated daily for $14 \mathrm{~d}$ with aliquots of cryopreserved cells from 6 isolates ( $\mathrm{n}=3$ native range, $\mathrm{n}=3$ invaded range) and the antibacterial activity was tested using the growth inhibition assay. This approach indicated that production of antibacterial metabolites began after $24 \mathrm{~h}$ of growth for the 6 bacterial isolates tested (Fig. 3). Overall, the length of incubation of the cultures did not have a significant effect on the inhibition of $V$. parahaemolyticus DI-ST-7 (regression, p > 0.05). However, overall, significant effects were seen in the concentration of CFS that was inhibitory (regression, $\mathrm{p}<0.0001$ ).

The inhibitory activity of isolate BZ14.1A was not significantly reduced by serial dilution of cultures incubated for $>5 \mathrm{~d}$ (ANOVA, $\mathrm{p}>0.05$; Fig. 3A). In the $25 \%$ CFS dilution, antibacterial metabolite production was variable across days, but the other concentrations of CFS $(100 \%, 50 \%$, and $12.5 \%)$ remained relatively stable throughout the $14 \mathrm{~d}$. The remaining 5 isolates exhibited between-day variability in the strength of pathogen inhibition for all concentrations.

\section{Examination of mucus extracts for antibacterial activity}

The volume of mucus collected from each fish was variable (15 to $25 \mathrm{ml}$ ), so it was not possible to determine what volume of mucus was appropriate for testing antibacterial activity. Instead, the concentration of freeze-dried samples was standardized for all chemical extractions at $1 \mathrm{mg} \mathrm{ml}^{-1}$ solvent. Using disk diffusion assays to evaluate the presence of antibacterial metabolites, the lionfish mucus extracts did not exhibit any activity on plates seeded individually with the 6 bacterial fish pathogens, 7 lionfish bacterial isolates, or 7 squirrelfish bacterial isolates. 


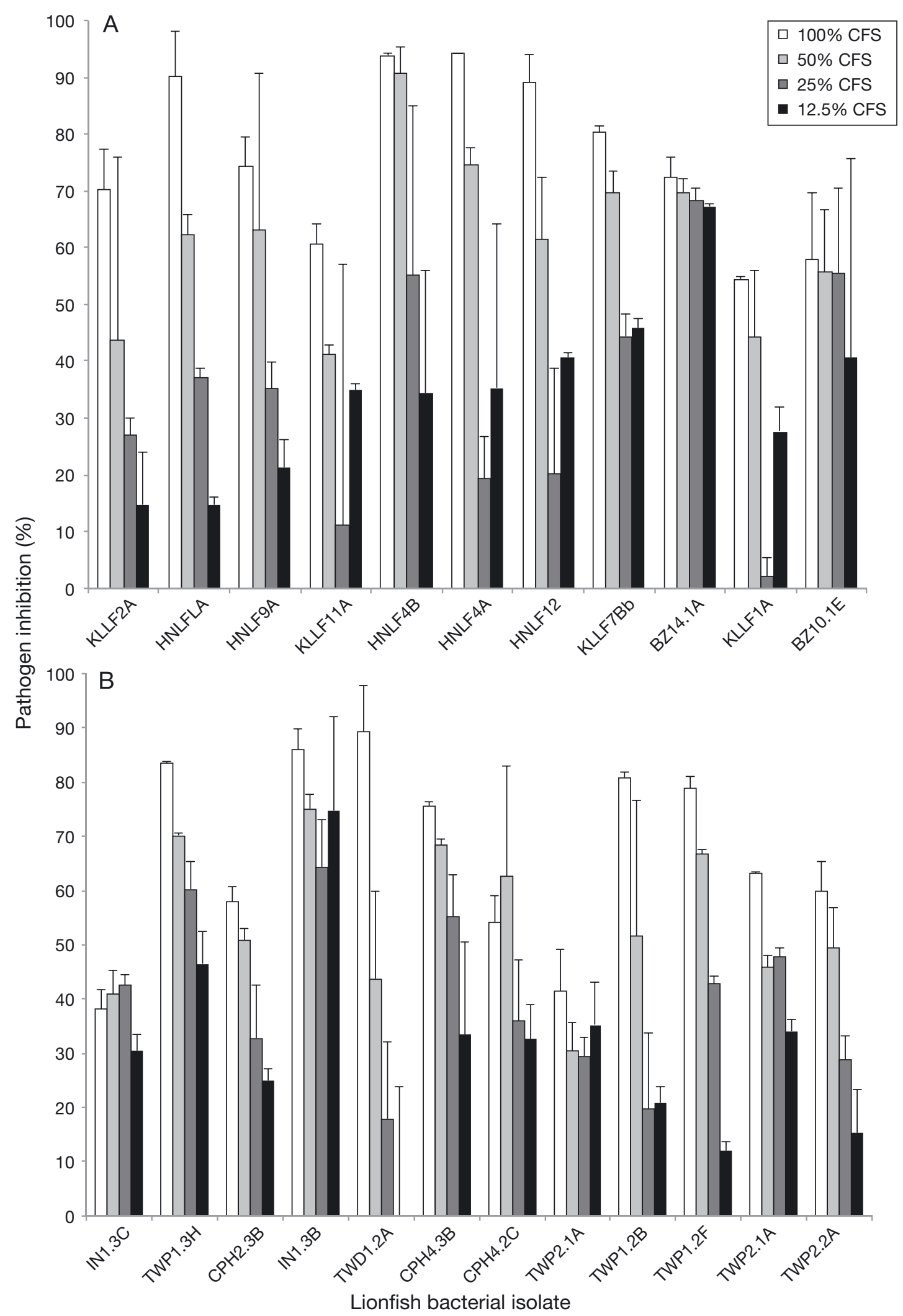

Fig. 2. Vibrio parahaemolyticus strain DI-ST-7 growth inhibition in growth inhibition assays using $100 \%, 50 \%$, $25 \%$, and $12.5 \%$ cell-free supernatant for the 23 isolates that showed activity against 2 or more of the 6 pathogens tested. Error bars (SD) represent triplicate wells per concentration of cell-free supernatant. Isolates from lionfish surfaces in the (A) invaded and (B) native range are shown 

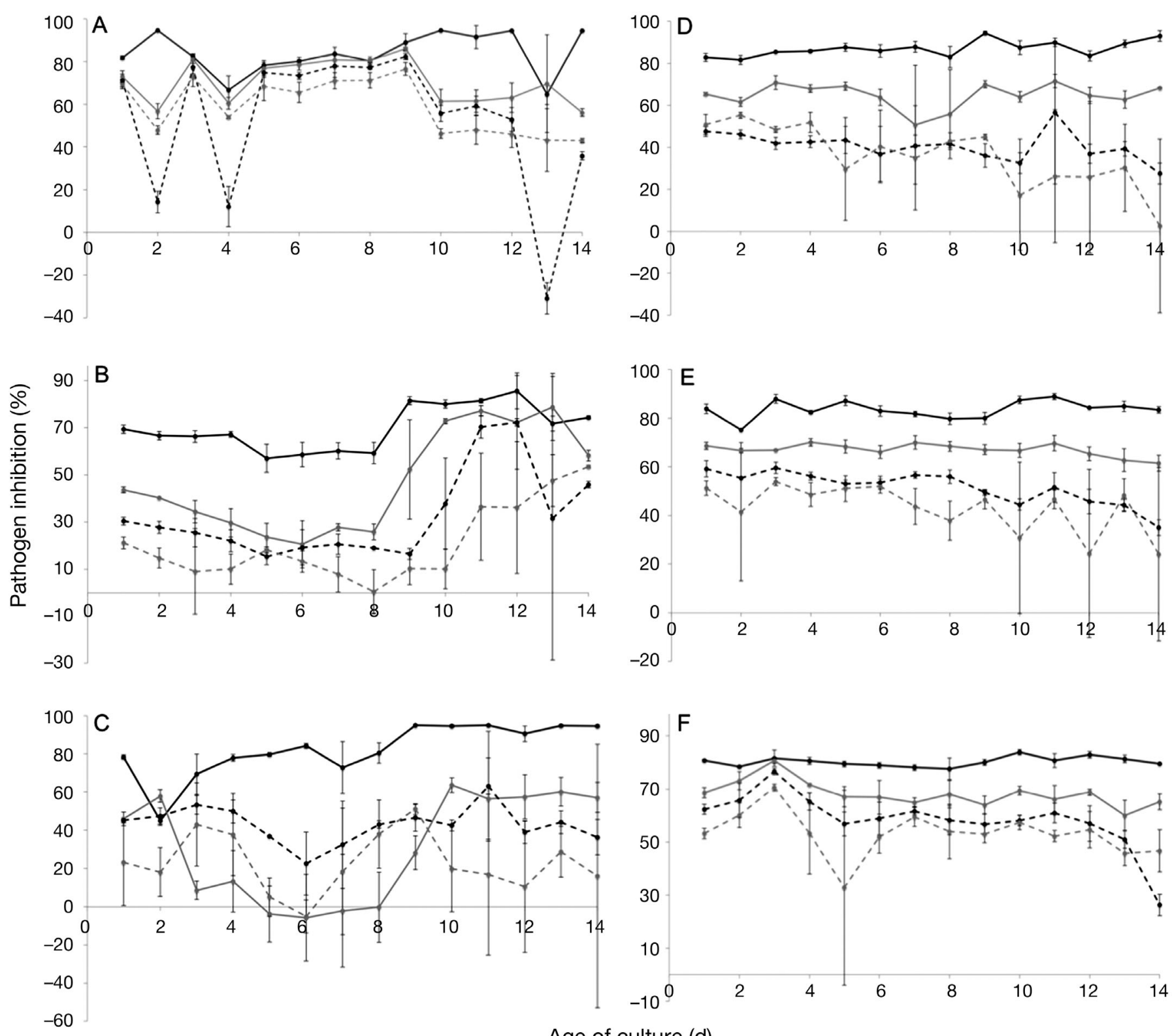

Age of culture (d)

Fig. 3. Pathogen inhibition was detected after $24 \mathrm{~h}$ of incubation for each of the 6 tested isolates: $100 \%$ cell-free supernatant (CFS; black lines), $50 \%$ CFS (gray lines), $25 \%$ CFS (black dashed lines), and $12.5 \%$ CFS (gray dashed lines). (A) Invaded

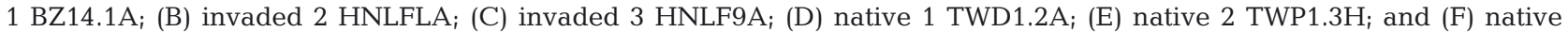
$3 \mathrm{CPH} 4.3 \mathrm{~B}$

\section{DISCUSSION}

Lionfish skin supports a diverse group of bacteria capable of producing antibacterial metabolites, with activity against one or more fish pathogens observed in more than a third of lionfish-associated bacterial isolates. Similar or higher levels of pathogen inhibition by associated bacterial communities were also found on healthy adult humans (Toshima et al. 2007) and brittlestars (Strahl et al. 2002). However, other studies in the marine environment reported that less than $20 \%$ of host-associated bacteria were able to inhibit pathogen growth (Dobretsov \& Qian 2002, Zhang et al. 2009, Leyton \& Riquelme 2010). This variability in pathogen inhibition by associated bacterial communities may explain differences in disease resistance between species or even individuals. Interestingly, only $18.5 \%$ (10 of 54 ) of the bacteria 
that demonstrated antibacterial activity yielded an amplification product for the presence of genes involved in the NRPS or PKS pathways, suggesting that alternative metabolites were used for their antibacterial activity.

Host species have been shown to use the chemical metabolites produced by their associated microorganisms to avoid infection by pathogens (Harder et al. 2003, O'Brien \& Wright 2011). For example, microorganisms isolated from the mucus of sole prevented the adhesion of Photobacterium damselae ssp. piscicida (Chabrillón et al. 2005). Similarly, rainbow trout harbored pseudomonads on their skin that inhibited the proliferation of Vibrio anguillarum (Spanggaard et al. 2001). However, the capacity for mucus-associated bacteria to inhibit or outcompete pathogens is highly variable (Lee et al. 2003), so harboring multiple strains of bacteria with the ability to produce antibacterial metabolites could serve as a bet-hedging mechanism for pathogen resistance. In fact, diverse fish-associated bacterial communities have been linked to greater resilience and disease resistance (Verschuere et al. 2000, Chabrillón et al. 2005). Invasive lionfish, which have a more diverse bacterial community than some native Bahamian fishes (Stevens \& Olson 2013), may use their bacterial community as a mechanism to aid in pathogen resistance, which would likely influence their ability to successfully establish in the invaded range.

Previous work demonstrated that invasive lionfish did not appear to harbor any known pathogenic or opportunistic bacteria on their skin (Stevens \& Olson 2013). However, several fish pathogens, including one of the pathogens used in the present study, $P$. damselae ssp. piscicida, were previously detected on the skin of Caribbean squirrelfish (Stevens \& Olson 2013). The antibacterial activity exhibited by lionfish-associated bacteria against known fish pathogens may explain the absence of these pathogens in the previous study. However, the present study assayed pathogen inhibition rather than investigated the mechanism(s) of activity, so we cannot comment on whether the pathogens were killed. The presence of biosynthetic genes for the production of potentially bioactive PKS and NRPS metabolites was evaluated but no other potential mechanisms of inhibition were assessed.

The diversity of lionfish-associated bacteria capable of inhibiting the fish pathogens was evident in the phylogenetic assessment. The taxonomic affiliations of these bacteria included several genera that are known to inhibit pathogen growth in other marine hosts and that were previously detected in lion- fish-associated bacterial communities (Stevens \& Olson 2013). Although the present study used cultivation-dependent approaches that are known to limit bacterial diversity, comparisons of the taxonomic identifications of our isolates to the lionfish bacterial clone libraries published previously (Stevens \& Olson 2013) showed considerable overlap. Members of the genera Alteromonas, Pseudoalteromonas, Tenacibaculum, and Vibrio and the phylum Bacteroidetes were recovered in both studies, indicating that these bacteria may be important components of the lionfish surface-associated bacterial community. For example, Vibrio spp. isolated from sole were shown to be active against $P$. damselae ssp. piscicida (Chabrillón et al. 2005). Bacillus pumilus, an isolate recovered in the present study but not found in the previous culture-independent study, inhibited V. parahaemolyticus and $V$. harveyi infections in shrimp (Hill et al. 2009). Vibrio spp. and Bacillus spp. present in the intestines and on the skin of flounder and Bacillus spp. associated with brittlestars were active against a suite of known fish pathogens (Strahl et al. 2002, Sugita et al. 2002). The present study isolated a Micrococcus sp., a member of the phylum Actinobacteria, with antibacterial activity while, interestingly, Chabrillón et al. (2005) failed to detect pathogen inhibition by multiple species of Micrococcus. However, each study utilized different suites of test pathogens, reinforcing the concept that antibacterial activity is likely limited to specific pathogens. Isolates most closely related to members of the Alteromonas and Pseudoalteromonas were commonly cultivated from both the native and invaded ranges. Members of these genera (which were split by Gauthier et al. 1995) are known to produce antibacterial metabolites active against both human and fish pathogens (Dopazo et al. 1988, Barja et al. 1989). The variability in pathogen inhibition by the isolates recovered in the present study and other studies further supports the role of diverse microbial communities in promoting disease resistance of their hosts.

The fish pathogens used in the present study are ubiquitous in tropical waters worldwide and cause fish disease in both the Indo-Pacific and Atlantic Oceans (Linkous \& Oliver 1999, Austin \& Zhang 2006, Farmer \& Hickman-Brenner 2006). As a result, differences in the activity of lionfish-associated bacteria against pathogens specific to the native or invaded range could not be assessed. Because of the lack of endemicity of fish pathogens to either the Indo-Pacific or Atlantic, it was not possible to fully explore whether lionfish, like other invasive organisms, escaped from pathogens through their estab- 
lishment in the invaded range (sensu Vermeij 2005). If fish pathogens specific to particular ranges can be identified, it would be an intriguing question for future studies. However, 2 ubiquitous fish pathogens, $V$. vulnificus and $V$. parahaemolyticus, are also considered pathogens of concern for humans (Linkous \& Oliver 1999, Farmer \& Hickman-Brenner 2006), making their control in the marine environment an interesting and timely issue.

The epidermal mucus of some fish contributes to innate immunity and responds to environmental shifts and pathogen exposure by altering the composition and/or rate of excretion of mucus (Ellis 1974, Subramanian et al. 2008). However, antimicrobial activity testing of mucus extracts currently remains limited and results vary by species of fish (Hellio et al. 2002, Subramanian et al. 2008). In the present study, although $\sim 1 / 3$ of the lionfish-associated bacteria obtained from lionfish mucus were active against one or more of the 6 bacterial fish pathogens, no antibacterial activity of lionfish mucus extracts was detected against any of the fish pathogens or fish-associated (lionfish and squirrelfish) bacteria. There are several possible reasons for this disparity in activity. First, a previous study found no known fish pathogens associated with lionfish mucus (Stevens \& Olson 2013), suggesting that skin conditions may not have required production of defensive molecules at detectable concentrations. Second, the concentration of freeze-dried mucus was standardized across samples prior to chemical extractions following Hellio et al. (2002), but did not take into account the size of the fish collected. Thus, it remains unknown whether the concentration tested was ecologically relevant. Chemical analyses of the activity of fish mucus have not examined the effect of correcting sample concentration for differences in fish size (Hellio et al. 2002, Bergsson et al. 2005, Subramanian et al. 2008, Bragadeeswaran et al. 2011). Thus, studies are needed to provide information regarding the antibacterial activity of fish mucus at ecologically relevant concentrations.

Previous work conducted in our laboratory indicated that lionfish retained a core bacterial community in both the native and invaded ranges, but that differences were apparent when the bacterial communities were examined by individual collection locations (Stevens \& Olson 2015). As no bacteria were found associated with lionfish eggs, vertical transmission of these communities was not expected (Stevens \& Olson 2013). In the present study, nearly half of the presumably environmentally acquired isolates from fish caught in the native range inhibited pathogen growth while nearly one-third of the isolates from the invaded range were active. Similar isolate diversity was found in both the native and invaded ranges and the percent of pathogen inhibition was not different between ranges, suggesting that the retained organisms may provide a beneficial function for the host through the inhibition of pathogen growth.

The continual exposure to potential pathogens requires that marine organisms are able to prevent the growth and proliferation of pathogens. The methods used in the present study did not consider the ecological relevance of antibacterial metabolite production as all experiments were conducted in vitro with pure cultures, but provided the framework for further analyses to determine whether laboratory results reflect the actual relationship between lionfish and their associated bacteria. Although lionfish mucus does not appear to prevent the growth of potential pathogens, the ability of their skin-associated bacteria to inhibit pathogen growth may be effective in preventing disease. By maintaining a high diversity of bacteria with the ability to inhibit pathogen growth throughout both the native and invaded ranges of the lionfish, it is likely this bacterial community plays a role in innate immune function and ultimately contributes to the invasive success of lionfish.

Acknowledgements. This research was funded in part by National Science Foundation (NSF) EAPSI (OSIE-1209695) and American Academy of Underwater Sciences Kathy Johnston fellowships awarded to J.L.S. Additional support was provided by NSF OCE-1214303 awarded to J.B.O. Thanks to D. Gochfeld, C.-W. Wang, C.-W. Chang, and A. Fogg for assistance with lionfish collections. Thanks also to A. Rice and V. Turberville for help performing growth curves. Lionfish collections were made with University of Alabama IACUC approval (protocol no. 11-358-2).

\section{LITERATURE CITED}

Austin B (2002) The bacterial microflora of fish. Sci World J 2:558-572

Austin B, Zhang XH (2006) Vibrio harveyi: a significant pathogen of marine vertebrates and invertebrates. Lett Appl Microbiol 43:119-124

- Ayuso-Sacido A, Genilloud O (2005) New PCR primers for the screening of NRPS and PKS-I systems in actinomycetes: detection and distribution of these biosynthetic gene sequences in major taxonomic groups. Microb Ecol 49:10-24

Barja JL, Lemos ML, Toranzo AE (1989) Purification and characterization of an antibacterial substance produced by a marine Alteromonas species. Antimicrob Agents Chemother 33:1674-1679

Bergsson G, Agerberth B, Jörnvall H, Gudmundsson GH 
(2005) Isolation and identification of antimicrobial components from the epidermal mucus of Atlantic cod (Gadus morhua). FEBS J 272:4960-4969

Bernadsky G, Rosenberg E (1992) Drag-reducing properties of bacteria from the skin mucus of the cornetfish (Fistularia commersonii). Microb Ecol 24:63-76

Bragadeeswaran S, Priyadharshini S, Prabhu K, Rani ARA (2011) Antimicrobial and hemolytic activity of fish epidermal mucus Cynoglossus arel and Arius caelatus. Asian Pac J Trop Med 4:305-309

Burke C, Thomas T, Lewis M, Steinberg P, Kjelleberg S (2011) Composition, uniqueness and variability of the epiphytic bacterial community of the green alga Ulva australis. ISME J 5:590-600

- Cahill MM (1990) Bacterial flora of fish: a review. Microb Ecol 19:21-41

- Chabrillón M, Rico RM, Balebona MC, Moriñigo MC (2005) Adhesions to sole, Solea senegalensis Kaup, mucus of microorganisms isolated from farmed fish, and their interaction with Photobacterium damselae subsp. piscicida. J Fish Dis 28:229-237

> Dobretsov SV, Qian PY (2002) Effect of bacteria associated with the green alga Ulva reticulata on marine micro- and macrofouling. Biofouling 18:217-228

> Dopazo CP, Lemos ML, Lodeiros C, Bolinches J, Barja JL, Toranzo AE (1988) Inhibitory activity of antibiotic producing marine bacteria against fish pathogens. J Appl Microbiol 65:97-101

Edwards U, Rogall T, Blocker H, Emde M, Bottger EC (1989) Isolation and direct complete nucleotide determination of entire genes: characterization of gene coding for $16 \mathrm{~S}$ ribosomal RNA. Nucleic Acids Res 17:7843-7853

Ellis AE (1974) Non-specific defense mechanisms in fish and their role in disease processes. Dev Biol Stand 49: 337-352

Ellis AE (2001) Innate host defense mechanisms of fish against viruses and bacteria. Dev Comp Immunol 25: 827-839

Farmer JJ III, Hickman-Brenner FW (2006) The genera Vibrio and Photobacterium. In: Dworkin M, Falkow S (eds) The Prokaryotes. Springer, New York, NY, p 508-563

- Fernandes JMO, Molle G, Kemp GD, Smith VJ (2004) Isolation and characterisation of oncorjycin II, a histone H1-derived antimicrobial peptide from skin secretions of rainbow trout, Oncorhynchus mykiss. Dev Comp Immunol 28:127-138

Ganguly S, Prasad A (2012) Microflora in fish digestive tract plays significant role in digestion and metabolism. Rev Fish Biol Fish 22:11-16

Gauthier G, Gauthier M, Christen R (1995) Phylogenetic analysis of the genera Alteromonas, Shewanella, and Moritella using genes coding for small-subunit rRNA sequences and division of the genus Alteromonas into two genera, Alteromonas (emended) and Pseudoalteromonas gen. nov., and proposal of twelve new species combinations. Int J Syst Bacteriol 45:755-761

Harder T, Lau SCK, Dobretsov S, Fang TK, Qian PY (2003) A distinctive epibiotic bacterial community on the soft coral Dendronephthya sp. and antibacterial activity of coral tissue extracts suggest a chemical modification against bacterial epibiosis. FEMS Microbiol Ecol 43:337-347

Hellio C, Pons AM, Baeupoil C, Bourgougnon N, Gal LY (2002) Antibacterial, antifungal and cytotoxic activities of extracts from fish epidermis and epidermal mucus. Int $\mathrm{J}$ Antimicrob Agents 20:214-219
Hill JE, Baiano JCF, Barnes AC (2009) Isolation of a novel strain of Bacillus pumilus from penaeid shrimp that is inhibitory against marine pathogens. J Fish Dis 32: 1007-1016

> Holmström C, Kjelleberg S (1999) Marine Pseudoalteromonas species are associated with higher organisms and produce biologically active extracellular agents. FEMS Microbiol Ecol 30:285-293

Lane DJ (1991) 16S/23S rRNA sequencing. In: Stackebrandt E, Goodfellow $M$ (eds) Nucleic acid techniques in bacterial systematics. John Wiley \& Sons, Chichester, p 115-175

Lee YK, Puong KY, Ouwehand AC, Salminen S (2003) Displacement of bacterial pathogens from mucus and Caco-2 cell surface by lactobacilli. J Med Microbiol 52: 925-930

Leyton Y, Riquelme C (2010) Marine Bacillus spp. associated with egg capsules of Concholepas concholepas (common name 'Loco') have an inhibitory activity toward the pathogen Vibrio parahaemolyticus. Microb Ecol 60: 599-605

Linkous DA, Oliver JD (1999) Pathogenesis of Vibrio vulnificus. FEMS Microbiol Lett 174:207-214

- O'Brien J, Wright GD (2011) An ecological perspective of microbial secondary metabolism. Curr Opinion Biotechnol 22:552-558

> Olsson JC, Westerdahl A, Conway PL, Kjelleberg S (1992) Intestinal colonization potential of turbot (Scophthalmus maximus) - and dab (Limanda limanda)-associated bacteria with inhibitory effects against Vibrio anguillarum. Appl Environ Microbiol 58:551-556

> Penesyan A, Kjelleberg S, Egan S (2010) Development of novel drugs from marine surface associated microorganism. Mar Drugs 8:438-459

> Ray AK, Ghosh K, Ringø E (2012) Enzyme-producing bacteria isolated from fish gut: a review. Aquacult Nutr 18: 465-492

> Sar N, Rosenberg E (1987) Drag reduction by Acinetobacter calcoaceticus BD4. Appl Environ Microbiol 53: 2269-2270

> Seow KT, Meurer G, Gerlitz M, Wendt-Pienkowski E, Hutchinson CR, Davies J (1997) A study of iterative type II polyketide synthases, using bacterial genes cloned from soil DNA: a means to access and use genes from uncultured microorganisms. J Bacteriol 179:7360-7368

Spanggaard B, Huber I, Nielson J, Sick EB and others (2001) The probiotic potential against vibriosis of the indigenous microflora of rainbow trout. Environ Microbiol 3: 755-765

> Stevens JL, Olson JB (2013) Invasive lionfish harbor a different external bacterial community than native Bahamian fishes. Coral Reefs 32:1113-1121

> Stevens JL, Jackson RL, Olson JB (2013) Slowing PCR ramp speed reduces chimera formation from environmental samples. J Microbiol Methods 93:203-205

> Stevens S, Olson JB (2015) Bacterial communities associated with lionfish in their native and invaded range. Mar Ecol Prog Ser 531:253-262

Strahl ED, Dobson WE, Lundie LL Jr (2002) Isolation and screening of brittlestar-associated bacteria for antibacterial activity. Curr Microbiol 44:450-459

Subramanian S, Ross NW, MacKinnon SL (2008) Comparison of antimicrobial activity in the epidermal mucus extracts of fish. Comp Biochem Physiol B 150:85-92

Sugita H, Okano R, Suzuki Y, Iwai D, Mizukami M, Akiyama 
N, Matsuura S (2002) Antibacterial abilities of intestinal bacteria from larval and juvenile Japanese flounder against fish pathogens. Fish Sci 68:1004-1011

Taylor MW, Schupp PJ, de Nys R, Kjelleberg S, Steinberg PD (2005) Biogeography of bacteria associated with the marine sponge Cymbastela concentrica. Environ Microbiol 7:419-433

Toshima H, Hachio M, Ikemoto Y, Ogasawara J and others (2007) Prevalence of enteric bacteria that inhibit growth of enterohaemorrhagic Escherichia coli O157 in humans. Epidemiol Infect 135:110-117

Vermeij GJ (2005) Invasion as expectation: a historical fact of life. In: Sax DF, Stachowicz JJ, Gaines SD (eds)

Editorial responsibility: Charles Birkeland, Honolulu, Hawaii, USA
Species invasions: insights into ecology, evolution and biogeography. Sinauer Associates, Sunderland, MA, p 315-340

Verschuere L, Rombaut G, Sorgeloos P, Verstraete W (2000) Probiotic bacteria as biological control agents in aquaculture. Microbiol Mol Biol Rev 64:655-671

> Videler H, Geertjes GJ, Videler JJ (1999) Biochemical characteristics and antibiotic properties of the mucous envelope of the queen parrotfish. J Fish Biol 54:1124-1127

Zhang W, Li Z, Miao X, Zhang F (2009) The screening of antimicrobial bacteria with diverse novel nonribosomal peptide synthetase (NRPS) genes from South China Sea sponges. Mar Biotechnol 11:346-355

Submitted: January 19, 2016; Accepted: June 1, 2016

Proofs received from author(s): July 18, 2016 